DOI https://doi.org/10.36059/978-966-397-233-6-2

Ярослав Калакура

\title{
Деміфологізація постатей тоталітарних режимів у контексті декомунізації та деколонізації української історіографії
}

\section{Demythologization of figures of totalitarian regimes in the context of decommunization and decolonization of Ukrainian historiography}

Self-purification from various myths, distortions, falsifications, and reproduction of true history is one of the important and relevant problems of both Ukrainian and Polish historiographies, which during imperial and totalitarian regimes were subjected to ideological insinuations, prejudices and false assessments of a number of events, facts, phenomena and figures. Putin's war against Ukraine gave an additional impetus to the reincarnation of imperial and Soviet myths, exacerbation of the "war of histories". The purpose of research is to clarify contemporary theoretical and methodological approaches to overcoming the consequences of mythologizing history, to outline directions for overcoming old ones and to prevent the creation of new myths and the construction of pseudo-heroes. The research methodology includes consistent adherence to the principles of historicism, anthropologism, refutation of false positions, civilizational, energetic and generational approaches, use of methods of historiographical criticism, comparative studies, modeling and own observations. Scientific novelty is conditioned by an in-depth analysis of the essence and mechanisms of mythologizing figures, its negative consequences, the presentation of new approaches to dispelling falsifications and distortions as a component of decolonization and decommunization of historical science and social consciousness. Conclusions. As a result of the research, three main directions of myth-making and distortion of historical truth in imperial, and thus in Soviet and contemporary Russian historiographies have been distinguished: a) appropriation of the history of Ukraine, its key figures; b) compromising real heroes, accusing them differently with the simultaneous imposition of mythologized Russian heroes under the guise of "common history" and "one people", glorifying their role in Ukrainian history; c) silence or rehabilitation of the names of criminals involved in the repression and destruction of the Ukrainian people.

Attention is drawn to the facts of constructing new fake heroes, in particular during the Russian-Ukrainian war and during election campaigns; it is emphasized that the demythologization of history, demystification of artificial 
myths, overcoming inferiority complexes harmful to the national revival, Little Russia and Little Europe identity remain a relevant task. Historians are intended to take an active social and civic position in the demythologization of history, to demonstrate their own integrity and impartiality.

Однією з ключових тенденцій сучасної світової історіографії має статиїі очищення від різного роду міфів, спотворень та фальсифікацій і відтворення правдивої історії кожного народу, ії персоналій. Ця проблема видається особливо актуальною для української та польської історіографій, які в часи імперських та тоталітарних режимів зазнали ревізій, інсинуацій і насадження упереджених та фальшивих оцінок цілої низки подій, фактів і явищ вітчизняної історії, особливо її ядра - антропологічної складової, тобто постатей. При цьому йдеться про руйнівні сліди не лише комунізації, а й імперської колонізації. Як засвідчує суспільна практика, деколонізація $є$ не менш складним, а в дечому навіть глибшим і тривалішим процесом, ніж декомунізація, особливо в контексті боротьби за самоідентифікацію українців і поляків, поглиблення їхніх взаємин. Австро-Угорська, а ще більшою мірою Російська імперії намагалися нав'язати своє уявлення про історію українців і поляків, зобразити їх одвічними ворогами, видати фактично окуповані терени за свої історичні території, щоб утвердитися на них. Послідовно нав'язувалися чужа мова, культура, топоніміка, свідомість, висувались концепції про один народ, спільну історію, спільних героїв і ворогів. Спотворення історичної пам'яті, міфологізація героїв, фальшиве трактування минувшини та сьогодення шляхом навмисної підміни або фабрикації джерел, фактів, поширення міфів, формування і насадження стереотипів мислення, наклеювання ярликів на інші країни й народи були складовим компонентом імперської політики Росії та технологіями, спрямованими на маніпуляцію історичною свідомістю. Сучасна російська історіографія не лише успадкувала цю ганебну традицію, а й довела технології створення образу внутрішнього і зовнішнього ворога до абсолютизації, не цураючись банальної фальсифікації, відвертої дезінформації, упереджених суджень, брехні, наклепів та ін. До того ж, нинішні московські історики оголосили про своє право 
на монополію “правдивого і об’єктивного” висвітлення не лише своєї історії, але й чужої, включаючи й українську та польську.

Хоча після розпаду Радянського Союзу в процесі деколонізації та декомунізації історичної науки чимало зроблено для подолання негативних наслідків міфологізації історії, спростування міфів, але багато з них, як і старих ідеологем, продовжують побутувати в суспільній свідомості, історичній пам'яті, в історіографічній спадщині, в практиках історієписання як постколоніальний і пострадянський синдром. Ці негативні явища підігріваються неоімперською політикою Російської Федерації, кремлівськими істориками, парадигмою “руского міра”, агентами ії впливу в Україні. Ось чому подальше очищення історії від імперських та комуністичних нашарувань і перекручень нашого минулого, від міфологізації його постатей залишається актуальним завданням як під кутом зору методологічних засад історіографії, так і для повсякденних дослідницьких практик. Від міфологізації історії застерігав видатний український філософ Мирослав Попович ще наприкінці 90-х рр. XX ст. (Попович М., 1998, с. 57-68), однак ці питання набули особливої гостроти в сучасних реаліях, коли деякі представники нинішньої влади та політикуму ностальгують за радянським минулим, декларують цінності, які аж ніяк не вписуються в контекст української національно-державницької ідеї та цінностей Революції Гідності.

Тема деміфологізації постатей тоталітарних режимів набуває особливої актуальності в умовах інформаційного суспільства та гібридних воєн. Злободенність і наукове значення її подальшого дослідження зумовлюються кількома чинниками: по-перше, вона все ще залишається в числі недостатньо досліджених і з'ясованих проблем як в історіографії, так і в історії загалом. Серед опублікованих праць з цієї проблематики заслуговують уваги студії В. Брехуненка, В. В’ятровича, В. Гриневича, Р. Іванченко, Г. Касьянова, О. Ковалевської, М. Лукінюка, В. Смолія, О. Толочка та ін. (Лукінюк М., 2003; Іванченко Р., 2006; Касьянов Г., 2013; В'ятрович В., 2014; Зашкільняк Л., 2015; Ковалевська 0., 2015; Почепцов Г., 2015; Брехуненко В., 2017; Гриневич В., 2020), в яких спростовується ціла низка міфів, успадкованих від імперського і радянського минулого, висвітлюються сучасні візії 
історії. Відрадно, що подібна проблематика критики фальсифікацій історії, спростування міфів, деколонізації історичної пам'яті наявна також у польській історіографії (Bodziany M., 2010; Sosnowska D., 2012; Jarząbek K., 2013). Окремих аспектів проблеми декомунізації історіографії, подолання синдрому комунізації торкався й автор даної розвідки (Калакура Я., 2016). Однак це лише початок роботи, оскільки тема настільки важлива і широка, що потребує продовження на основі системного підходу. По-друге, антропологічним поворотом української гуманітаристики, переходом від “історії подій” до “історії людей”. Орієнтація істориків на людиноцентризм має супроводжуватись відтворенням правдивих і об'єктивних оцінок усіх дійових осіб історичного процесу (Рафальський О., Калакура Я., Коцур В., Юрій М., 2020). По-третє, живучістю стереотипів про так званих героїв, сконструйованих російською і радянською історіографіями, замовчуванням багатьох імен справжніх борців за волю і незалежність України, а також істориків, на чию творчість було накладено табу. По-четверте, новими викликами, пов'язаними 3 тривалою агресію і війною путінської Росії проти України, яка дала додатковий поштовх реінкарнації імперських та радянських міфів, загостренню "війни історій" (Гойман 0., 2015). Історія стала ключовим сегментом гібридної війни боротьби не стільки за території, скільки за свідомість людей. Навіть у форматі російської академічної науки обговорюється питання про можливість і доречність відродження Імперії. Зокрема, в 2013 р. в Москві захищена кандидатська дисертація, присвячена досвіду імперських політичних технологій в організації великих держав (Лопухов Д., 2013). Ці та інші чинники переконливо доводять важливість і необхідність поглибленого аналізу сутності міфологізації постатей, її негативних наслідків для української історіографії, розвінчування фальсифікацій і спотворень як складової деколонізації та декомунізації історичної науки і суспільної свідомості.

Мета пропонованої розвідки полягає в тому, щоб, з одного боку, з'ясувати деякі теоретико-методологічні підходи до подолання наслідків міфологізації історії та її постатей, а з другого, окреслити напрями, за якими новітня історіографія розвінчує 
застосування методу конструювання міфів в процесі колонізації, комунізації і совєтізації українського суспільства, з'ясувати наскільки ефективно вона сприяє їхньому подоланню та запобіганню створенню нових міфів і псевдогероїв.

Задля реалізації цієї мети видається доцільним хоча б стисло торкнутися живучості деяких стереотипів, успадкованих від колонізації суспільної свідомості засобами історичної науки на тлі їх реставрації в сучасній російській історіографії, яка рішуче відмовилась від оцінок ранньосовєтських часів, коли офіційно використовувався ленінський концепт "колоніальна політика царизму”, а царська Росія фігурувала як “в'язниця народів”. На думку німецьких істориків Я. Янсена та Ю. Остергаммеля, деколонізація є мультифакторним процесом, який включає у себе не лише політичну та економічну складову, а й соціокультурну та свідомісну (Jansen J.C., 2013). Вона безпосередньо зачіпає питання історичної пам'яті, а значить покликана сприяти іï очищенню від нашарувань колонізаційного минулого. Хоча Андреас Каппелер вважав, що Україна не була класичною колонією Російської імперії, але прояви колоніалізму простежувались у відносинах російського центру та української периферії у сфері політичного, економічного, а ще більшою мірою культурного життя (Velychenko S., 2002; Мотиль 0., 2009).

Українська історія фактично понад чотири століття перебувала в тіні російської історіографії та відповідних імперських інтерпретацій, що призводило до поширення таких явищ і комплексів як малоросійство, москвофільство та меншовартість. Як зазначав Я. Дашкевич, українці століттями “жили в атмосфері псевдоісторії - кривавих, злочинних “творців історії”, які могли творити історію лише таку, як вони самі - криваву, злочинну” (Дашкевич Я., 1993). Маніпулюючи історичними фактами і довільно трактуючи джерела, російські історики не лише намагалися привласнити історію України, а й створювали та насаджували в свідомості українців негативний образ їхніх сусідів, насамперед Польщі, як “історичного ворога Росії”. В. Татіщев, М. Погодін виводили коріння антипольських настроїв зі ставлення православ'я до католицької віри, вдаючись до упередженої інтерпретації офіційних документів, давніх літописів та усної 
творчості. Зокрема М. Карамзін, який походив із татарського роду Кара-Мурзи (з Криму) і був прихильником так званого “братства слов'ян”, зазначав, що поляки ніколи не будуть росіянам ані щирими братами, ані вірними союзниками, а Польщу називав “хворобою на тілі слов'ян” (Карамзин Н., 1862). Подібну точку зору підтримували В. Ключевський, С. Соловйов, а відтак С. Платонов, М. Покровський та ін., які хоч і вважали погляди попередників архаїчними, але щодо зовнішньополітичних орієнтирів продовжували відносити Польщу до “історичних ворогів” Росії, спільних і для українського народу. Контекст “історичного ворога" слугував обгрунтуванням ключової ролі Росії у чотирьох поділах Польщі $(1772,1793,1795,1939)$, зрештою і в повоєнній окупації та насадженні там просталінського режиму. На платформі “спільного ворога” після втрати Україною державності та її окупації Росією на початку 1920-х рр. була побудована парадигма “спільної історії, модель якої всіляко насаджувалась в історичній науці та суспільній свідомості. Не випадково, совєтська історіографія розглядала Польщу як форпост наступу антикомунізму і латинства, створювала міфи про iї діячів. У цьому зв'язку можна згадати лідера відродження Польщі, маршала Юзефа Пілсудського, ім'я якого тривалий час вживалося не інакше як “фашистский диктатор”. Недовір'я та підозрілість у ставленні до Польщі зберігались і після 1948 р., коли там реально був встановлений просовєтський режим. Воно не змінилося і в путінській Росії, яка дорікає Польщі та її лідерам як за участь у НАТО, так і за активну підтримку України в євроатлантичній інтеграції.

Принагідно зазначимо, що навіть у сучасній російській історіографії проглядаються поодинокі критики імперського колоніалізму. Петербурзький історик Євген Анісімов розглядає російську національну свідомість як імперську та вбачає їі коріння в минулому деспотичної держави, яке сягає середини XVI ст. (Анисимов Е., 2012). Війна Росії проти України актуалізувала саме ті аспекти української колективної пам'яті, які безпосередньо пов'язані з ідеями національної самопожертви, патріотизму та збройного опору загарбникам. У цьому зв'язку необхідно деміфологізувати тих політичних і військових діячів 
Російської імперії, які сприяли перетворенню України на колонію, нищили українців. Йдеться про московських правителів Івана IV Грозного, Олексія Михайловича, Петра I, Катерину II, Миколу I, Олександра II, Миколу II, полководців Аракчеєва, Брусілова, Денікіна, Єрмолова, Корнілова, Кутузова, Меншикова, Потьомкіна.

При певній схожості колонізації та комунізації історії, остання мала певну специфіку, зумовлену комуністичною ідеологією. Оскільки совєтський режим сповідував ідеологеми класової боротьби, визнавав лише два кольори - білий та чорний і керувався гаслом “хто не з нами, той проти нас", то, відповідно, й суспільство було поділене на героїв та ворогів. За допомогою міфів створювався образ героя або ворога, причому формат критеріїв був настільки штучний, що вчорашні герої навіть із вищих ешелонів влади нерідко ставали ворогами і злочинцями. Можна згадати цілу низку розвінчаних комуністичною владою соратників Леніна та лідерів жовтневого перевороту, вищих державних посадовців, принаймні, Троцького, Зінов'єва, Бухаріна, а згодом і Сталіна, Берію, Жукова, так звану “антипартійну групу” 1950-х рр. на чолі з Малєнковим, Кагановичем i Молотовим. Сказане стосується й відомих партійних і державних діячів України - Затонського, Косіора, Любченка, Петровського, Постишева, Скрипника, Чубара, Шелеста та ін. Цей механізм глорифікації людей, а відтак їхнього розвінчування застосовувався і до істориків. Прикладом тут може слугувати Матвій Яворський - творець першого підручника з історії України на марксистській основі, який був піднятий до звання академіка і члена президії ВУАН, а відтак звинувачений у контрреволюційній діяльності та відступництві від марксизму і розстріляний на Соловках за те, що ідеалізував куркульство та дрібнобуржуазні націоналістичні партії, не визнавав авангардну роль російського пролетаріату (Роєнко В., 2008). Терміни “яворщина”, як і “грушевщина”, упродовж десятиліть застосовувались для таврування істориків, чиї погляди не збігалися з офіційною совєтською історіографією.

Ярлики ворогів народу і буржуазних націоналістів навішувались на багатьох діячів української літератури 
імистецтва,зокремаМихайлаБойчука,ОстапаВишню,МаркаВороного, Сергія Єфремова, Леся Курбаса, Миколу Куліша, Олександра Олеся, Василя Свідзінського, Василя Симоненка, Людмилу Старицьку-Черняхівську, Василя Стуса, Миколу Хвильового, Гната Хоткевича, Юрія Яновського та багатьох інших. До ворогів України були віднесені й діячі української церкви Василь Липківський, Іван Огієнко, Володимир Романюк, Мстислав Скрипник, Йосип Сліпий, Андрей Шептицький та ін.

Імперська традиція фальсифікації і спотворення історичної правди, що бере свій початок, як уже зазначалося, з часів В. Татіщева, М. Карамзіна, М. Погодіна, С. Соловйова, була не просто успадкована комуністичним режимом, а й досягла свого апогею. Широко застосовувались фальсифікація та підробка документів, стирання людей з фотографій, вимаровування текстів в листах, прізвищ у літературі тощо.

Разом із жовтневим переворотом 1917 року в прихованому вигляді була реанімована москвоцентрична модель історії Росії під гаслом “Москва - Третій Рим”. Москва отимала статус столиці Російської Федерації, а відтак СРСР. “Третій Рим” став центром Третього Інтернаціоналу. Віра в Бога була замінена вірою в побудову комунізму. В такий спосіб міф більшовицької революції і комуністичного майбутнього ліг на ідею, започатковану в добу князювання Василя III (1505-1533), коли представник Московського православ'я монах Філофей заявив: “Два Рими впали, третій стоїть, а четвертому не бути”. Відтоді у московитів починає утверджуватися думка про всемогутність й “богообраність” Москви як - “Третього і останнього Риму”“. Заради цієї ідеї-маячні, яка насильно поширювалась і насаджувались у Московії, було пролито чимало крові, в тому числі й української. Консервуючи гасло “Москва - третій Рим”, царизм прагнув обнулити історичну роль Києва як в історії українського державотворення, так і в прийнятті християнства. Усім, хто відчував себе давніми українцями і православними в умовах Московської держави, а відтак Російської імперії була визначена роль молодших братів, менших русичів тобто малоросів. 3 того часу московська історіографія шляхом підміни і фальсифікації джерел, їх великодержавницької інтерпретації невпинно 
претендує на державницьку, науково-культурну і духовну спадщину Києва та Галича, їхніх видатних діячів. Спотворюючи факти, путінські історики намагаються довести російськість київських, галицьких і волинських князів, починаючи від Аскольда, Ольги, Володимира Великого, Ярослава Мудрого, Володимира Мономаха, Романа Мстиславича, Данила Галицького і закінчуючи Ярославом Ярославичем. Продовжуючи привласнення собі спадщини України, Росія вдається до встановлення пам'ятників, присвоєння імен державним установам, розміщення зображень українських діячів на банкнотах. Це одна з ланок амбітної парадигми “руского міра" і реваншистських планів Путіна повернути Україну в поле російського впливу. Зокрема, в охоронній зоні ЮНЕСКО біля Кремля постав пам'ятник Володимирові Хрестителю, щобу такий спосіб прив'язати частину нашої історії до себе, видати її за "рускую”. В цьому ніщо інше, як прояв боязні кремлівських володарів визнати, що Росія - це штучна держава, створена в результаті завойовницьких воєн та окупації чужих земель. Вона й досі не відмовилась від експансіоністської політики щодо сусідніх країн, насильно об'єднує на величезній території народи, які не мають відношення до історії росіян і нічим не пов'язані з ними. Не випадково, що й державна символіка сучасної Росії багато в чому зберігає або поєднує ознаки імперських символів, що мають нагадувати самолюбивим московитам велич колишньої імперії, побудованій на міфах. Російська пропаганда, маніпулюючи так званим спільним комуністичним минулим, дуже вдало використовує ностальгію за совєтськими часами, намагається відновити московитам статус "старшого брата”, зберегти і утвердити власний історичний наратив на пострадянському та постсоціалістичному просторі, поширити його на світ.

Деякі сучасні кремлівські історики так подають події, ніби до почату колонізації на територіях майбутньої імперії неросійські народи не мали свого минулого. Такі вигадки використовуються для поширення впливу Росії на Україну, Білорусь, Молдову, Закавказзя, Середню Азію. До цього важливо додати, що в Росії продовжує зберігатися міф про унікальність російського соціополітичного простору, який насправді не позбавлений 
імперського забарвлення.

Комуністична міфологізація постатей в історичній науці України почалася 3 російсько-більшовицької воєнної агресії, окупації та повалення УНР, із совєтізації Української академії наук, створення наукових установ марксистського спрямування, із знищення наукової школи М. Грушевського, що призвело до іiі маргіналізації та периферійності, до консервації синдрому колоніальної меншовартості і малоросійства. Що це означало на практиці з погляду антропології та міфологізації icmopiï? Борці за національне визволення і самостійну соборну українську державу, починаючи від гетьманів I. Виговського, П. Дорошенка, I. Мазепи, провідників національно-визвольного руху, Української революції 1917-1921 рр. В. Винниченка, М. Грушевського, М. Міхновського, С. Петлюри, П. Скоропадського, $€$. Петрушевича і закінчуючи діячами ОУН та УПА Є. Коновальцем, А. Мельником, С. Бандерою, Я. Стецьком, Р. Шухевичем, оголошувались ворогами і підлими зрадниками українського народу. Натомість всіляко возвеличувались організатори комуністичного режиму в Україні, його прислужники і так звані будівники соціалізму, носії цінностей “нової радянської людини” ("homo soveticus"): В. Антонов-Овсієнко, С. Артем, В. Боженко, €. Бош, С. Будьонний, Я. Гамарник, С. Гоппнер, П. Дибенко, О. Засядько, Е. Квірінг, С. Косіор, Г. Котовський, М. Криленко, М. Майоров, Д. Мануїльський, С. Сабуров, Ю. Пятаков, М. Хатаєвич, М. Щорс, Й. Якір та ін. (деякі з них згодом були оголошені ворогами народу та репресовані).

Процес міфологізації та комунізації наніс велику шкоду історичній науці в Росії, а ще більше в Україні (Станчак 0., 2006, с. 216). Він призвів до того, що вона перестала бути наукою в класичному розумінні слова, а перетворилася на догідливу служницю режиму та засіб маніпуляції суспільною свідомістю. Дехто вважає, ніби концепт “совєтський тоталітаризм" тотожний “сталінізму”, тобто має вузькі хронологічні межі. Насправді, він охоплює всю совєтську історію, а це означає, що комунізація не припинялась і в постсталінські часи, причому в добу брежнєвщини вона дуже тісно зрощувалася із “кагебізацією” країни, а в Україні ще й з маланчукізмом часів Щербицького. Тоталітарна 
доба залишила травматичний спадок як у історичній свідомості, так і в ментальності українців.

Говорячи про історіографічну ситуацію доби брежнєвського застою, треба зазначити, що чимало істориків (поміж них і я) були вимушені маскувати свої політичні та ідейні переконання, приховувати національну свідомість, демонструвати показну лояльність і готовність до співпраці з владою. Образно кажучи, відбувався конфлікт півкуль мозку: “права" сторона не розуміла "ліву”, формувалася подвійна мораль. Віталій Яремчук виділяє в середовищі тогочасних істориків декілька груп (Яремчук В., 2009, с. 124), зокрема: а) завзяті догматики, сталіністи і ортодокси, які ретельно прислужували режиму, послідовно й сліпо виконували партійні настанови, поширюючи фальшиві погляди та стереотипи; б) конформісти і нонконформісти, які кон'юнктурно або й пасивно сприймали існуючі стандарти історіописання, пристосовувались до умов, а на тлі “відлиги” допускали деякі розходження із традиційним каноном; в) націонал-комуністи, які намагалися трактувати події і факти 3 позицій ідеології комунізму 3 національним обличчям; г) замасковані опозиціонери та історики-дисиденти. Відповідно влада виявляла найбільшу довіру і прислухалася до представників першої групи, які й виступали головними конструкторами міфологізації історії.

Ще на рубежі 1920-1930-х рр. більшовики створили цілу індустрію конструювання міфів та псевдогероїв, пріоритетну роль в якій посідала партійна пропаганда та засоби масової інформації, установи науки, освіти і культури, а також твори літератури й мистецтва. Активну участь у цьому процесі брали й деякі письменники, зокрема Ярослав Галан, Юрій Збанацький, Григорій Епік, Олександр Корнійчук, Івана Кочерга, Валентин Собко та ін., які за принципами партійності та соцреалізму створювали міфи про Сталіна як “вождя і батька”, про “мудрість політики компартії, про Совєтський Союз як “велику дружню сім’ю народів”, конструювали образ “героя-партійця”, ідеальної совєтської людини" та глорифікували їі. Перед спокусою прислужитися системі не встояли й окремі класики української літератури як Микола Бажан, Максим Рильський, Павло Тичина 
та ін. (Федорів У., 2017, с. 28-30). На технологіях цієї індустрії, часто за участю журналістів, письменників та кінематографістів, продукувались образи фейкових героїв: Павки Корчагіна, Олега Кошового, Трохима Лисенка, Олександра Матросова, Павлика Морозова, Олександра Стаханова та ін. Сказане стосується й створення Дмитром Медведєвим міфу про совєтського чекіста-терориста Миколу Кузнєцова (Ніколая Грачова) у книзі “Сильні духом”. В роки Другої світової війни він, здійснюючи терористичні акти проти вищих посадових осіб гітлерівського режиму, спровокував масові каральні операції окупантів проти мирного населення. Московська пропаганда створила легенду про “героїчну смерть Кузнєцова в боях з бандерівцями”, хоча $€$ незаперечні свідчення, що він підірвав себе гранатою. Йому було посмертно присвоєно звання Героя Радянського Союзу, встановлювались пам'ятники, створювались фільми, м. Вараш на Рівненщині в 1977-2016 рр. носило назву Кузнецовськ (Романчук 0., 2007, с. 15-16).

До міфологізації як інструменту комунізації (до речі, термін належав Леніну) широко залучались й історики як “бійці ідеологічного фронту”, а з їх участю відбувалася міфологізація історичної науки, внаслідок чого вона втрачала свої природні функції і перетворювалась у “зброю партії в боротьбі проти ворогів соціалізму і народу”. Більшовики націоналізували не лише фабрики і заводи, але й історію, встановивши повний контроль за історієписанням. 3 власного досвіду знаю, як істориків навіть у постхрущовські часи змушували дотримуватися офіційного канону, обслуговувати режим, оспівувати і виправдовувати політику і діяльність КПРС. До незгідних з лінією партії та офіційним каноном застосовувались репресії і переслідування. На моїй пам'яті було немало жертв цієї політики, згадаймо, принаймні, Олену Апанович, Петра Арсенича, Сергія Білоконя, Михайла Брайчевського, Ярослава Дзиру, Раїсу Іванову, Михайла Марченка, Валентина Мороза, Юрія Пінчука, Федора Шевченка та ін., яких переслідували за їхні погляди, позбавляли права на друк, а іноді й роботи. Натомість нерідко підтримувались різного роду псевдоісторики, які хоч реально історією не займалися, зате виявляли виняткову запопадливість 
у “розвінчуванні ідейних збочень” і “буржуазно-націоналістичних фальсифікацій” у працях інших. Пригадую, як деякі з них із власної ініціативи приходили до відділу науки і навчальних закладів ЦК КПУ з доносами, заявами або надсилали чорні рецензії та анонімки.

Комунізація та міфологізація історичної науки носила примусовий і тотальний характер, вона торкнулась усіх її розділів, особливо історії України, яка перебувала під особливим наглядом спецслужб, під пресом комуністичної ідеології та соціально-економічного детермінізму, зазнала деукраїнізації, вихолощування з неї всього, що пов'язане з національною свідомістю, національним патріотизмом, включаючи й справжніх героїв та рідну мову. Засобом уніфікації історичних оцінок була їхня канонізація в офіційних документах партії, як, наприклад, у зловісних Тезах ЦК КПРС 1953 р. узаконювалось так зване “возз'єднання України з Росією”, положення про те, що російський, український і білоруський народи походять від одного кореня давньоруської народності, яка створила давньоруську державу Київську Русь, а видатних діячів українського державотворення В. Винниченка, М. Грушевського, С. Петлюру було названо “платними агентами іноземного імперіалізму” (Тези про 300-річчя возз'єднання України... 1954, с. 4-5). Оця ідея "спільної колиски" надовго засіла в головах не лише маргінальних росіян і малоросів, а й деяких сучасних істориків України.

Пріоритетна роль у стандартизації історичних оцінок відводилась історикам КПРС, що виступали як представники “цариці" над іншими науками і дістали в народі назву “номенклатурних”. Звичайно, серед численних істориків партії було й немало добре підготовлених і грамотних, але зустрічалася й сірість. Як жартували в часи брежнєвщини, "в суспільні науки пішов середняк". Заради справедливості треба сказати, що багато істориків партії, які генетично зберігали українськість, спокутуючи провину за конформізм і прислужницттво режиму, успішно виконали важливу місію на етапі відновлення суверенітету та незалежності України, забезпечивши перехід до викладання історії України, створення відповідних навчально-методичних комплексів і підручників, а також підготовку молодої генерації істориків. 
Працюючи над проблемою зміни поколінь в українській історіографії (Калакура Я.С., 2020, с. 157) і спілкуючись з людьми різного віку, роблю висновок, що у спадок сучасникам залишилась така патологія, як постколоніальний і посткомуністичний синдром історичної науки і істориків. Термін “синдром" має грецьке походження і буквально означає нагромадження, зберігання, консервацію певних комплексів, успадкованих від минулого. На цій основі розвивається відповідна патологія мислення. Сам синдром транзитний, він має здатність передаватись новим поколінням і виступає як травмована свідомість людини або реакція травмованої психіки на повсякдення (Рябчук М., 2011, с. 13-14).

Його віруси проникли і до свідомості пострадянської генерації. I це природно, адже вона формувалася під впливом старшого покоління, живучи в суспільстві, яке, не позбувшись багатьох рудиментів тоталітарного минулого, опинилося в полоні олігархів. До того ж, декомунізаційні закони, включаючи закон про доступ до архівів спецслужб, Верховна Рада ухвалила лише на 25-му році незалежності України, а їхнє виконання наштовхується на спротив консерваторів та проросійських сил. Тим не менше, вони заклали сприятливі умови та набагато ширші можливості для відтворення історичної правди щодо ключових постатей української історії, для очищення монументального простору історичної пам'яті нашого народу. Уже демонтовано більше 1300 пам'ятників Леніну, сотні пам'ятників іншим діячам кривавого режиму, пов'язаних із злочинами проти людства, якими була засіяна вся Україна, але немало ще залишилось.

Як показала практика, перейменувати назви населених пунктів і вулиць, знести пам'ятники ідолам комунізму дуже важливо, але для зламу тоталітарної свідомості, подолання комплексу малоросійства та мешовартості цього недостатньо. Цьому процесу бракує належного наукового і просвітницького супроводу. Якось біля Центрального державного архіву громадських об’єднань України незнайомий чоловік запитав мене, хто такий Алмазов. Про росіянина Кутузова він знав, а про нашого генерала доби УНР навіть не чув. То чому б не присвятити таким постатям наукові дослідження, дисертаційні роботи? Тим більше, що сучасна історіографія переживає кризу теми. Поряд з багатьма 
новими і актуальними темами фігурує чимало штучно актуалізованих дріб'язкових проблем та другорядних постатей, переформатованих із радянських кліше. Можна згадати не так давно захищені дисертації про Постишева, Косіора, Скрипника, Любченка, Щербицького та ін.

Якими є найхарактерніші симптоми “синдрому комунізації" істориків, що наклався на тотальну корупцію та олігархізацію суспільства? Це методологічна розгубленість, покірне очікування директив зверху, ідеологічна зацикленість, догматичне мислення, російськоцентризм, цитатно-ілюстративне історієписання, довільне ставлення до джерел, або навпаки, їхня абсолютизація, відсутність власної позиції, неприйняття плюралізму поглядів, прислужництво окремим політичним силам, висвітлення історії України у відриві від світового історичного процесу. Чимало носіїв цього синдрому не лише залишились в обіймах старих соціогуманітарних схем, ностальгуючи за комуністичним минулим, а й готові його захищати, демонструють розгубленість перед сучасними викликами, переживають депресію. Не секрет, що деякі історики з деформованою свідомістю все ще продовжують сповідувати марксистську методологію, глорифікують радянську дійсність, її героїв, багато хто з них, отримавши свободу творчості, не зуміли нею розпорядитися, а дехто розгубився у методологічних і світоглядних орієнтирах. Маємо винести уроки із сепаратистсько-антиукраїнських процесів, які відбувалися в Криму, на Донбасі та деяких інших регіонах, де впродовж чверті століття активно діяли українофоби, агенти російського впливу, наполегливо підживлювали комуністичний синдром, консервували совєтські стереотипи, демонстративно використовували комуністичну та/або проросійську символіку, включаючи й портрети Сталіна та георгіївські стрічки. Деякі викладачі історії України, зомбовані комуністичною пропагандою і розчулені ностальгією за “щасливим" минулим, продовжували плисти за радянськими сценаріями, заперечуючи російсько-більшовицьку окупацію України, голодомор, масовий характер репресій, руйнівні наслідки етноциду і тотальної русифікації, замовчуючи при цьому масштаби українського національно-визвольного і опозиційного рухів. 
Це простежувалося в спробах консервації рудиментів радянського режиму і в навчально-методичній літературі, в проблематиці, а ще більше у змісті дисертаційних робіт. Тепер цілком очевидними є наслідки цих явищ: за даними соціології, мало не третина жителів України, передусім людей старшого і похилого віку ностальгує за радянським минулим. Більшою мірою це стосується жителів Півдня і Сходу, російськомовних людей, етнічних росіян та ін. Там, де синдром комунізації отримав найбільше поширення, де “заморожувалися" совєтські кліше і монументальні пам'ятники комуністичним вождям, там тепер російська адміністрація та окупаційні війська.

Одним із симптомів живучості комплексів комунізації в сучасній практиці історієписання є стереотип про "пріоритет ідеології і політики над науковістю”, звичка ставити політичну доцільність вище історичної правди. Пересторогою цього явища можуть слугувати праці дослідників, спрямовані на викриття злочинів комуністичного режиму, на руйнування і спростування совєтських стереотипів і міфів, на доведення неспроможності спроб їх симпатиків видати крах комунізму за фатальну випадковість, наслідок “викривлення" ідеї або як результат “підривної діяльності Заходу”. Маємо декілька позитивних прикладів протидії міфотворчості, зокрема книгу “Ревізія історії: російська історична пропаганда та Україна, в якій українські історики дослідили низку наративів російських авторів, поширюваних у Фейсбуці, та довели їхню наукову неспроможність (Ревізія історії... 2019). На жаль, подібних праць дуже мало, особливо тих, що стосуються персоналізації історичного процесу. Це ще раз засвідчує, наскільки важливо, з одного боку, підвищувати методологічну зрілість українських істориків, повніше використовувати досвід зарубіжних країн, зокрема Польщі, Латвії, Литви, Естонії, Словаччини, Чехії та ін., які швидше позбуваюся рудиментів комуністичної доктрини, а з другого, глибше досліджувати на особистісному рівні психологічні аспекти творчого процесу різних поколінь у тоталітарну добу. При цьому необхідно враховувати, що із синдромом комунізації пов'язаниі не лише вкорінені в історіографії радянські міфи, а й своєрідний спосіб мислення окремих істориків, насамперед залишки “совкової” 
свідомості, що виявляються у фанатичній вірі в радянські ідеологічні міфи, в рабській психології, в популістській риториці, агресії та максималізмі. Совок живе минулим і ненавидить сучасні новації, він прихильник твердої руки і ворог демократії та західних цінностей.

Чи є запобіжники міфотворчості? Звичайно, є. Насамперед, це професіоналізм, почуття відповідальності і гідності історика. По-друге, науковий підхід до оцінки постатей. Маємо навчитися змальовувати образ людини такою, якою вона була в реальному житті, без прикрас чи навішування ярликів. Акцент треба робити не стільки на те, ким і яким був той чи інший персонаж у минулому, скільки на те, ким і яким він став. Можна взяти за приклад постать відомого історика і громадського діяча української діаспори Мирослава Січинського, яка діаметрально протилежно та далеко неоднозначно оцінюється в українській і польській історіографіях. Як відомо, у 20-річному віці він застрелив галицького намісника Анджея Потоцького і став героєм у націоналістичних колах. Його було засуджено до смертної кари, яку цісар замінив на довічне ув'язнення, а згодом Січинський утік із в'язниці й опинився в еміграції, де еволюціонував від націоналізму до радянофільства. Польська громадськість однозначно засудили цей вчинок, а історики потрактували його як прояв тероризму. Таку ж позицію зайняв Андрей Шептицький, оцінивши подію як акт політичного терору. Викликає подив намагання деяких наших дослідників героїзувати поступок М. Січинського, а відтак і його життя. Автори апелюють до того, що він листувався з М. Грушевським (Мицик Ю., Тарасенко I., Щестюк Т., 2010, с. 64-67), товаришував з Дмитром Вітовським - згодом державним секретарем військових справ ЗУНР, був автором важливих наукових студій. То хто ж він: вбивця, герой, патріот? Так ось не треба робити з таких та подібних людей ані ворогів, ані патріотів. Треба оцінювати їх без ідеологічної упередженості, тобто змальовувати їх такими, якими вони були насправді.

Підсумовуючи, ще раз зазначимо, що деміфологізація постатей тоталітарних режимів винятково актуальна і важлива складова деколонізації та декомунізації української історіографії, продиктована необхідністю рішучого очищення нашої історії від 
фальсифікацій і спотворень, від псевдогероїв і фейків. У імперській, а відтак у совєтській і сучасній російській історіографіях простежується три основних напрями спотворення історичної правди. Це привласнення історії України, ії ключових постатей, компрометація справжніх героїв, накидання на них різного року звинувачень 3 одночасним нав'язуванням міфологізованих російських героїв під виглядом “спільної історії” та “одного народу”, глорифікації їхньої ролі в українській історії, або ж замовчування злочинів проти українського народу. Суспільна свідомість українців все ще наповнена як старими, так і новими міфами, ідеологемами, міфологемами, що завдають великої шкоди та роблять людей вразливішими до впливу інформаційної війни. Тому деміфологізація історії, демістифікація штучних міфів, створення власної національної міфології та запровадження реміфологізації $€$ актуальною науковою і практичною проблемою. Історики, представники інших галузей гуманітаристики не можуть не реагувати на факти конструювання нових фейкових героїв у сучасних умовах, що особливо проявляється під час виборчих кампаній. Разом з тим, як справедливо зазначають 0. Салата (Салата 0., 2018, с. 59) та інші автори, позитиві герої потрібні, оскільки вони сприяють патріотичному вихованню, консолідації суспільства, але в жоднім разі не штучні чи фальшиві, які наносять велику шкоду, деморалізують людей. На думку О. Гойман (Гойман 0., 2016, с. 163), створення і розповсюдження серед українства позитивних міфів має сприяти прискоренню процесу національної самоідентифікації; консолідації нації в протистоянні агресивній пропагандистській міфології Російської Федерації; перетворенню позитивної міфології в одну з форм нової української ідеології; подолання шкідливих для національного відродження комплексів меншовартості, малоросійства та малоєвропейсва. Такі постаті у нас є. Це, наприклад, герої Небесної сотні, учасники російсько-української війни на Донбасі, медики, які виявили героїзм і жетровність у боротьбі з COVID-19 та багато інших.

Порушені тут питання актуальні ще й тому, що поряд з процесом декомунізації та деколонізації нас очікує деокупація Криму та частини Донбасу (Російська окупація і де окупація України:... 2016). Поняття “деокупація” стало складовоюнинішньої 
стратегії подолання наслідків російської експансії, яке передбачає усунення слідів панування намісників російського режиму і терористів, цілої низки демографічних, економічних та гуманітарних проблем. Політика окупаційної влади цілком вписуються в поняття "російського колоніалізму”, його різних форм XIX-XX ст. Російські найманці впродовж шести років ведуть шалену антиукраїнську пропаганду, поширюють фейки, маніпулюють фактами на тлі урочистих вручень нагород та вихвалянь лідерів так званих “ЛНР” і “ДНР", їхніх збройних угруповань. Цю псевдореальність щоденно транслюють проросійськи налаштовані ЗМІ, спрямовані на реанімацію совєтських стереотипів. Події, які там відбуваються, можна кваліфікувати як третю хвилю колонізації Росією окупованої частини території України.

I насамкінець. Видається також доцільним наголосити на необхідності глибше осягнути ідею французької школи “Анналів" про активну соціальну і громадянську позицію історика, його доброчесність і неупередженість та спільними зусиллями шляхом критичного мислення зреалізувати п'ять “д”: деколонізацію, деімперіалізацію, дерусифікацію, деміфологізацію та деатизацію української історіографії.

\section{Література}

Попович М. Міфологія в суспільній свідомості посткомуністичної України. Дух і Літера. 1998. № 3-4. С. 57-68.

Лукінюк М.В. Обережно: міфи! Спроба системного підходу до висвітлення фальшувань історії України. К. : Вид-во імені Олени Теліги, 2003. 576 с.

Іванченко Р.П. Історія без міфів : навч. посібник. К. : МАУП, 2006. 624 с.

Касьянов Г., Смолій В., Толочко О. Україна в російському історичному дискурсі: проблеми дослідження та інтерпретації. К. : Інститут історії України. 2013. 128 с.

В'ятрович В. Україна. Історія з грифом “Секретно”. Х. : Кн. клуб “Клуб Сімейного Дозвілля", 2014. 511 с.

Зашкільняк Л. Радянські історичні міфи в сучасній історіографії: “старее вино в нових міфах". Світло й тіні українського раданського історіописання : матеріали міжнародної наукової конференції (Київ, Україна, 22-23 травня 2013 р.) / за ред В. А. Смолія. К., 2015. С. 17-31. 
Ковалевська 0. Звільнення простору. Декомунізація як деколонізація візуального простору українських міст. Український тиждень. 2015. 26 листопада.

Почепцов Г. Сучасні інформаційні війни. К. : Вид. дім “Києво-Могилянська академія", 2015. 498 с.

Брехуненко В. Війна за свідомість. Російські міфи про Україну та їі минуле. К., 2017. 280 с. Гриневич В. Війни пам'ятей як конфлікт постколоніального та імперського дискурсів. Україна модерна, 2020. 28 c.

Bodziany M. Stereotypy narodowościowe w profilach stereotypowej percepcji żołnierzy wielonarodowych jednostek wojskowych. 2010. Zeszyty Naukowe. Wyższa Szkoła Oficerska Wojsk Lądowych im. gen. T. Kościuszki. No 3. S. 398-418.

Sosnowska D. Ograniczenia i możliwości krytyki postkolonialnej. Historyka. 2012. T. XLII. S. 89-99; Jarząbek K. Przełamywanie stereotypów kulturowych. Spotkania międzykulturowe. Literaturoznawstwo, kultura. 2013. T. 1. S. 108-116.

Калакура Я.С. Конструювання образу ворога як технологія маніпуляцій російської історіографії та пропаганди. Україна-Європа-Світ. Міжнародний збірник наукових праць. Серія: Історія, міжнародні відносини. Вип. 18. Тернопіль, 2016. С. 179-188.

Рафальський 0.0., Калакура Я.С., Коцур В.П., Юрій М.Ф. Антропологічний код української цивілізації і культури. У 2-х кн. : Кн. 1. К. : ІПіЕНД ім. І.Ф. Кураса, 2020. 432 с. С. 6.

Гойман 0. Реінкарнація радянських міфів у сучасній інформаційній війні. Людинознавчі студії. Серія: Філософія. Вип. 32. 2015. С. $133-147$.

Лопухов Д.А. Имперские политические технологи как способ организации больших государств: политолоический анализ отечественного опыта : автореф. дисс. ... канд. полит. наук. M., 2013. 22 c.

Jansen J.C., Osterhammel J. Dekolonisation: Das Ende der Imperien. München, 2013.144 s.

Velychenko S. The Issue of Russian Colonialism in Ukrainian Thought. Ab Imperio. 2002. №. 1. Р. 332-334 ; Мотиль 0. Підсумки імперій: занепад, розпад і відродження. Київ : Критика, 2009. 200 с.

Дашкевич Я. Росія, Україна та союзи 1919-1922 рр. Україна вчора і нині. К. : Б.в. 1993.192 с. С. 52.

Карамзин Н.М. Письмо к императору Александру I после розговора с ним о Польше в 1819 г. О древней и новой России в ее 
политическом и гражданском отношениях. Берлин : Schneider, 1862. 223 с. С. 126.

Анисимов Е.В. Императорская Россия. СПб. : Питер, 2012. 640 с.

Роєнко B.I. М. І. Яворський - історик України: життя і наукова діяльність : автореф. дис. ... канд. іст. наук. Запоріжжя, 2008. 21 с.

Станчак 0. Росія: Міфотворчість як деструктивний фактор в історії. Вісник Львівського університету. Серія журналістики. 2006. Вип. 28. 224 с.

Яремчук В. Минуле України в історичній науці УРСР післясталінської доби. Острог, 2009. С. 124.

Федорів У. “Головні герої” соцреалістичних текстів: герой-партієць. Вісник КНУ ім. Тараса Шевченка. Серія: Літературознавство. Мовознавство. Фольклористика. 1(27). К., 2017. С. 28-30.

Романчук 0. Ніколай Кузнєцов: кінець легенди агента-терориста. Універсум 2007, ч. 5-6. С. 15-16.

Тези про 300-річчя возз'єднання України з Росією (1654-1954рр.), схвалені ЦК КПРС. К. : Політвидав України, 1954. С. 4-5, 12.

Калакура Я.С. Зміна поколінь істориків як методологічний та світоглядний діалог в українській історіографії (кінець XIX - перше двадцятиріччя XXI ст.) Український історичний журнал. 2020. Ч. 4. С. 150-168.

Рябчук М. Постколоніальний синдром. Спостереження. К. : К.І.С., 2011.13-14.

Ностальгія за радянським минулим. URL: http://www.nrcu.gov.ua/ news.html?newsID=93596

Ревізія історії. Російська історична пропаганда та Україна / Я. Грицак, К. Галушко, Я. Примаченко, Г. Єфіменко, С. Громенко, I. Гоменюк, О. Ілюк, О. Сороцинська, А. Кадельник. К. : К.І.С., 2019. 99 c.

Мицик Ю, Тарасенко I, Щестюк Т. Листи М. Січинського до М. Грушевського. Наукові записки НаУКМА. 2010. Т. 104. С. 64-67.

Салата 0.0. Виховання патріотизму в умовах нових суспільно-політичних реалій. Формування патріотичної та громадянської свідомості учнів: теорія і практика : моногр. К. : Київ. ун-т ім. Б. Грінченка, 2018. 172 с. С. 58-66.

Гойман О. Позитивний міф як спосіб консолідації українства. Українознавчий альманах. Вип. 19. 2016. С. 161-164.

Російська окупація і де окупація України: історія, сучасні загрози та виклики сьогодення. К. : “МП Леся”, 2016. 348 с. 